\title{
EFEKTYWNOŚĆ GOSPODAROWANIA I POZYCJA RYNKOWA PUBLICZNYCH SPÓLEK INNOWACYJNYCH W POLSCE
}

\section{Wstęp}

Polska pod względem poziomu innowacyjności na tle innych krajów Unii Europejskiej wypada bardzo niekorzystnie. W rankingu Innovation Union Scoreboard ${ }^{1}$ opublikowanym w roku 2013 Polska zajmuje 24 lokatę, a średni wzrost poziomu innowacyjności był w naszym kraju niższy niż 1\%. Za taki stan rzeczy w głównej mierze odpowiadają niskie nakłady na działalność badawczo-rozwojową polskich przedsiębiorstw. Choć przedsiębiorcy zdają sobie sprawę z potencjału płynącego z innowacji ${ }^{2}$, to nie ma to bezpośredniego przełożenia na rynek. Niewątpliwie dobrym stymulatorem takiej działalności jest w skali makro stworzenie dogodnych warunków ze strony państwa. W przypadku sfery mikro jednym z ważniejszych czynników mogących skłonić przedsiębiorstwa do działalności badawczo-rozwojowej jest możliwość oszacowania płynących z niej wymiernych korzyści finansowych, a także dostęp do kapitału.

Celem artykułu jest weryfikacja efektywności gospodarowania i pozycji rynkowej podmiotów innowacyjnych na tle innych przedsiębiorstw. W części empirycznej opracowania uwzględniono przedsiębiorstwa, których akcje notowane są na Giełdzie Papierów Wartościowych w Warszawie oraz na rynku NewConnect, a ich wyniki finansowe poddane zostały analizie statystycznej mającej na celu zweryfikowanie twierdzenia o wyższej efektywności przedsiębiorstw innowacyjnych oraz uzyskiwanych przez nie wynikach rynkowych.

\section{Działalność innowacyjna przedsiębiorstw w Polsce}

Motywów do podejmowania działalności innowacyjnej w przedsiębiorstwach jest wiele. Jedne prowadzić mogą do stworzenia nowego produktu, inne z kolei do ulepszenia już istniejących. Innowacje wiążą się nie tylko z produktową sferą działalności, ale także $\mathrm{z}$ aspektami marketingowymi, organizacyjnymi czy procesowymi. Bez względu na motyw, celem takich działań jest przede

\footnotetext{
Doktorant, asystent, Katedra Zarządzania Przedsiębiorstwem, Wydział Zarządzania UŁ.

${ }^{1}$ Innovation Union Scoreboard 2013. Enterprise and Industry, European Union 2013, s. 10-11.

2 Jesteśmy w ogonie innowacyjności, ,Rzeczpospolita”, 27.06.2013.
} 
wszystkim utrzymanie lub poprawa pozycji konkurencyjnej przedsiębiorstwa, która powinna znaleźć swoje odzwierciedlenie w wynikach finansowych. Jedną z ważniejszych barier innowacyjności jest konieczność wydatkowania środków finansowych na działalność badawczo-rozwojową.

$\mathrm{Z}$ raportu opublikowanego przez firmę Deloitte ${ }^{3}$ wynika, że w przypadku $88 \%$ przedsiębiorstw biorących udział w badaniu prowadzona jest działalność badawczo-rozwojowa, a żaden respondent spośród pozostałych $12 \%$ nie jest $\mathrm{w}$ pełni przekonany, że ich podmioty nie ponoszą wydatków na sferę $\mathrm{B}+\mathrm{R}$. $\mathrm{W}$ grupie przebadanych podmiotów dominują firmy, które na działalność $\mathrm{B}+\mathrm{R}$ przeznaczają od 1 do $3 \%$ wypracowanych przychodów ze sprzedaży $(31 \%)$. Więcej niż 5\% swoich przychodów na $\mathrm{B}+\mathrm{R}$ przeznacza ok. 36\% przebadanych przedsiębiorstw, co na tle regionu (32\%) jest wynikiem poprawnym. Do dalszego zwiększania nakładów na działalność innowacyjną niezbędne są jednak dodatkowe kapitały. Najpowszechniej wykorzystywanym źródłem finansowania przedsiębiorstw są kapitały własne ${ }^{4}$. Aby je pozyskać, zarządzający organizacjami powinni zwracać baczną uwagę na tworzenie i utrwalanie wartości dla akcjonariuszy ${ }^{5}$. Ma to znaczenie szczególnie w przypadku przedsiębiorstw innowacyjnych, w których ryzyko związane $\mathrm{z}$ tymi przedsięwzięciami może być znacząco wyższe niż w przedsiębiorstwach prowadzących „tradycyjny” biznes ${ }^{6}$.

Większość badań prowadzonych w USA i w krajach Europy Zachodniej dowiodła pozytywnego wpływu innowacji na wartość rynkową przedsiębiorstw $^{7}$. W przypadku rynku polskiego brak jest, według wiedzy autora, jednoznacznych wyników uwzględniających wspomnianą zależność. W dalszej części artykułu przeprowadzona zostanie zatem próba oszacowania efektywności publicznych przedsiębiorstw innowacyjnych oraz zestawienie tych wyników ze wskaźnikami rynkowymi.

\footnotetext{
${ }^{3}$ Poland Corporate R\&D Report 2013, Deloitte, June 2013, s. 6.

${ }^{4}$ P. Pomykalski, Finansowanie innowacji przedsiębiorstwa, [w:] S. Bakalarczyk, P. Pomykalski (red.), Innowacyjność organizacji, Difin, Warszawa 2008, s. 97.

${ }^{5}$ C. Szuszyński (red.), Przedsiębiorstwo. Wartość. Zarządzanie, PWE, Warszawa 2007, s. 110

${ }^{6}$ Ż. Jabłońska, B. Socha, Efektywność gospodarowania a wycena rynkowa przedsiębiorstw innowacyjnych na polskim rynku kapitałowym, [w:] P. Urbanek (red.), Ekonomia i zarzadzanie $w$ teorii i praktyce. Polityka ekonomiczna i zarzadzanie przedsiębiorstwem $w$ warunkach kryzysu gospodarczego, Wyd. UŁ, Łódź 2011, t. 3, s. 348.

${ }^{7}$ Zob. R. Parthasarathy, H. Chenglei, S. Aris, Impact of Dynamic Capability on Innovation, Value Creation and Industry Leadership, „IUP Journal of Knowledge Management” 2011, vol. 9, Issue 3, s. 59-73; M. Appolloni, R. Corigliano, A. Duqi, G. Torluccio, The Market Value of Innovation, „European Journal of Economics, Finance \& Administrative Sciences” 2011, vol. 8, Issue 36, s. 166.
} 


\section{Zakres przedmiotowy i mierniki wykorzystane w badaniu}

Empiryczna część opracowania ma na celu zbadanie, czy przedsiębiorstwa pretendujące do miana innowacyjnych 1) osiągają przeciętnie wyższą efektywność gospodarowania, 2) ich akcje są postrzegane przez inwestorów jako atrakcyjniejsza lokata kapitału niż akcje pozostałych przedsiębiorstw. Badaniem objęto wszystkie spółki, których akcje są przedmiotem obrotu na polskim rynku regulowanym. Pierwszą grupę podmiotów stanowiły przedsiębiorstwa innowacyjne, które zostały sklasyfikowane $\mathrm{w}$ rankingu firm innowacyjnych, opublikowanym w ramach dodatku do gazety „Rzeczpospolita” („Lista 2000. Polskie przedsiębiorstwa") ${ }^{8}$. W analizie uwzględniono 20 z 60 spółek ujętych w rankingu, których akcje są jednocześnie w obrocie giełdowym (Giełda Papierów Wartościowych w Warszawie i rynek NewConnect). Drugą grupę przedsiębiorstw - benchmark, do którego porównywane będą wyniki osiągnięte przez firmy innowacyjne, stanowiło 791 przedsiębiorstw, których akcje pozostają w obrocie giełdowym i nie zostały zakwalifikowane do grupy pierwszej.

Dane liczbowe, niezbędne do przeprowadzenia badania, zebrano wykorzystując bazę danych „Amadeus” wydawaną przez Bureau Van Dijk ${ }^{9}$. Opracowanie objęło wyniki finansowe przedsiębiorstw za lata 2008-2012.

Pomiaru efektywności gospodarowania przedsiębiorstw dokonano z wykorzystaniem powszechnie stosowanych wskaźników rentowności kapitału własnego (ROE), rentowności aktywów (ROA) z wykorzystaniem zysku przed opodatkowaniem oraz wskaźnika marży zysku. Wskaźniki rynkowe - cena do zysku (P/E) oraz cena do wartości księgowej (P/BV) odzwierciedlały ocenę przedsiębiorstw przez inwestorów giełdowych. Porównanie uzyskanych wyników oparto na 5-procentowej średniej obciętej (w celu wyeliminowania wpływu na wyniki obserwacji skrajnych) oraz przedziałach ufności dla wartości średniej obliczonych z wykorzystaniem pakietu statystycznego SPSS.

Autor zdecydował się w pierwszym kroku analizy na weryfikację założenia o wyższej aktywności innowacyjnej tych podmiotów w porównaniu z pozostałymi firmami stanowiącymi benchmark. Wynikało to przede wszystkim z charakteru wykorzystanego rankingu przedsiębiorstw innowacyjnych, którego podstawą było badanie ankietowe. $\mathrm{W}$ tabeli 1 zaprezentowano wyniki dotyczące liczby patentów będących w posiadaniu analizowanych podmiotów. Wynika $\mathrm{z}$ niej, że przedsiębiorstwa zakwalifikowane do grupy innowacyjnych $\mathrm{w}$ roku 2012 były właścicielami zdecydowanie większej liczby patentów niż pozostałe firmy. Potwierdza to także przedział ufności dla średniej liczby patentów, który w przypadku firm innowacyjnych mieścił się znacząco powyżej wyniku grupy porównawczej.

\footnotetext{
8 „Lista 2000. Polskie przedsiębiorstwa”, dodatek do gazety „Rzeczpospolita”, 24.10.2012 r., s. 53.

${ }^{9}$ www. amadeus.bvdinfo.com; stan na 29.07.2013 r.
} 
Tabela 1. Średnia obcięta i przedziały ufności dla średniej liczby patentów w analizowanych grupach przedsiębiorstw w latach 2008-2012

\begin{tabular}{|c|c|c|c|}
\hline \multicolumn{3}{|c|}{ Wyszczególnienie } & 2012 \\
\hline \multirow{3}{*}{ Benchmark } & \multicolumn{2}{|c|}{ 5-procentowa średnia obcięta } & 0,1865 \\
\hline & \multirow{2}{*}{$\begin{array}{l}\text { 95-procentowy przedział } \\
\text { ufności dla średniej }\end{array}$} & dolna granica & 0,4299 \\
\hline & & górna granica & 2,5258 \\
\hline \multirow{3}{*}{$\begin{array}{l}\text { Przedsiębiorstwa } \\
\text { innowacyjne według } \\
\text { rankingu „Rzeczpospo- } \\
\text { litej” }\end{array}$} & \multicolumn{2}{|c|}{ 5-procentowa średnia obcięta } & 6,7778 \\
\hline & \multirow{2}{*}{$\begin{array}{l}\text { 95-procentowy przedział } \\
\text { ufności dla średniej }\end{array}$} & dolna granica & 1,2266 \\
\hline & & górna granica & 16,2734 \\
\hline
\end{tabular}

Źródło: opracowanie własne (dotyczy tabel 1-8).

\section{Wyniki badań w zakresie efektywności gospodarowania przedsiębiorstw innowacyjnych}

Niniejsza część opracowania poświęcona została analizie efektywności gospodarowania w wyodrębnionych grupach podmiotów. Analiza średnich wyników wskaźnika ROE (tabela 2) pozwala stwierdzić, że efektywność wykorzystania kapitałów własnych $\mathrm{w}$ grupie przedsiębiorstw innowacyjnych była istotnie wyższa niż w grupie kontrolnej we wszystkich analizowanych latach. Różnica uzyskanych wyników między grupami, biorąc pod uwagę 5-procentową średnią obciętą wskaźnika ROE (wykres 1), była najwyższa w roku 2012 (ok. 10 p.p.), a najniższa w roku 2010 (ok. 0,7 p.p.).

Tabela 2. Średnia obcięta i przedziały ufności dla średniej wartości wskaźnika ROE (w \%) w analizowanych grupach przedsiębiorstw w latach 2008-2012

\begin{tabular}{|c|c|c|c|c|c|c|c|}
\hline \multicolumn{3}{|c|}{ Wyszczególnienie } & 2012 & 2011 & 2010 & 2009 & 2008 \\
\hline \multirow{3}{*}{ Benchmark } & \multicolumn{2}{|c|}{ 5-procentowa średnia obcięta } & $-0,0100$ & 5,3206 & 9,3029 & 5,0442 & 5,3791 \\
\hline & \multirow{2}{*}{$\begin{array}{l}\text { 95-procentowy } \\
\text { przedział ufno- } \\
\text { ści dla średniej }\end{array}$} & \begin{tabular}{|l} 
dolna \\
granica
\end{tabular} & $-16,1854$ & $-7,8471$ & $-0,7010$ & $-6,6198$ & $-6,4115$ \\
\hline & & $\begin{array}{l}\text { górn } \\
\text { gran }\end{array}$ & $-4,4660$ & 3,9487 & 10,9560 & 4,7626 & 6,6763 \\
\hline \multirow{3}{*}{$\begin{array}{l}\text { Przedsiębiorstwa } \\
\text { innowacyjne } \\
\text { według rankingu } \\
\text { „Rzeczpospolitej” }\end{array}$} & \multicolumn{2}{|c|}{ 5-procentowa średnia obcięta } & 10,2900 & 12,2040 & 10,0204 & 13,9203 & 14,0272 \\
\hline & \multirow{2}{*}{$\begin{array}{l}\text { 95-procentowy } \\
\text { przedział ufno- } \\
\text { ści dla średniej }\end{array}$} & $\begin{array}{l}\text { dolna } \\
\text { granica }\end{array}$ & 5,6717 & 8,1085 & 5,7988 & 1,1640 & 5,6634 \\
\hline & & $\begin{array}{l}\text { górna } \\
\text { granica }\end{array}$ & 15,7251 & 17,0205 & 16,7066 & 22,4606 & 23,2627 \\
\hline
\end{tabular}


Na wykresie 1 zauważyć można również, że wyniki grupy podmiotów innowacyjnych na przestrzeni czterech lat wyróżniały się mniejszymi wahaniami. Także przedziały ufności dla średniej wartości omawianego wskaźnika w grupie firm innowacyjnych znajdowały się powyżej przedziałów ufności grupy kontrolnej.

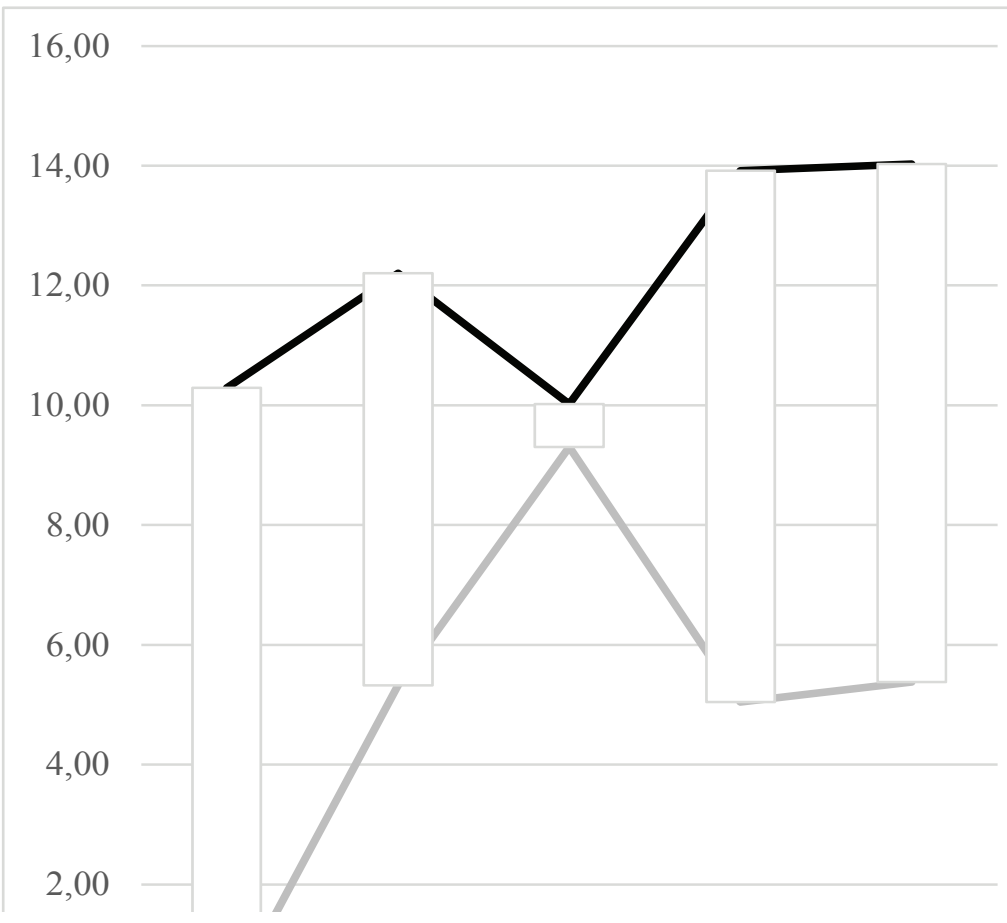

Wykres 1. Średnia obcięta wartość wskaźnika ROE (w \%) w analizowanych grupach przedsiębiorstw w latach 2008-2012

Źródło: opracowanie własne (dotyczy wykresów 1-5).

Średnia rentowność aktywów spółek innowacyjnych, podobnie jak w przypadku rentowności kapitałów własnych jest wyższa niż wskazuje benchmark. Największą różnicę w rentowności zaobserwować można w roku 2009 (ok. 6,7 p.p.), najniższą zaś w roku 2010 (ok. 1,58 p.p.). Z analizy przedziałów ufności dla średniej wartości wskaźnika wynika, że - ze współczynnikiem ufności na poziomie 0,95 - rentowność aktywów przedsiębiorstw innowacyjnych we wszystkich analizowanych latach wynosiła minimum 3\%. W przypadku spółek $\mathrm{z}$ grupy kontrolnej tylko w roku 2010 dolna granica przedziału ufności miała wartość dodatnią. 
Tabela 3. Średnia obcięta i przedziały ufności dla średniej wartości wskaźnika ROA (w \%) w analizowanych grupach przedsiębiorstw w latach 2008-2012

\begin{tabular}{|c|c|c|c|c|c|c|c|}
\hline \multicolumn{3}{|c|}{ Wyszczególnienie } & 2012 & 2011 & 2010 & 2009 & 2008 \\
\hline \multirow{3}{*}{ Benchmark } & \multicolumn{2}{|c|}{ 5-procentowa średnia obcięta } & 0,8458 & 2,7033 & 4,2701 & 1,4792 & 2,0306 \\
\hline & \multirow{2}{*}{$\begin{array}{l}\text { 95-procentowy } \\
\text { przedział ufno- } \\
\text { ści dla średniej }\end{array}$} & $\begin{array}{l}\text { dolna } \\
\text { granica }\end{array}$ & $-2,2572$ & $-0,0256$ & 2,3888 & $-1,5385$ & $-0,7554$ \\
\hline & & $\begin{array}{l}\text { górn } \\
\text { gran }\end{array}$ & 0,7083 & 2,7872 & 5,3675 & 1,7821 & 2,8125 \\
\hline \multirow{3}{*}{$\begin{array}{l}\text { Przedsiębiorstwa } \\
\text { innowacyjne } \\
\text { według rankingu } \\
\text { „Rzeczpospoli- } \\
\text { tej” }\end{array}$} & \multicolumn{2}{|c|}{ 5-procentowa średnia obcięta } & 6,3339 & 6,9702 & 5,8495 & 8,1629 & 7,6719 \\
\hline & \multirow{2}{*}{$\begin{array}{l}\text { 95-procentowy } \\
\text { przedział ufno- } \\
\text { ści dla średniej }\end{array}$} & \begin{tabular}{|l} 
dolna \\
granica
\end{tabular} & 3,3595 & 4,4127 & 3,1580 & 4,1895 & 3,1491 \\
\hline & & $\begin{array}{l}\text { górna } \\
\text { granica }\end{array}$ & 10,3620 & 10,8111 & 10,8719 & 13,3647 & 13,4209 \\
\hline
\end{tabular}

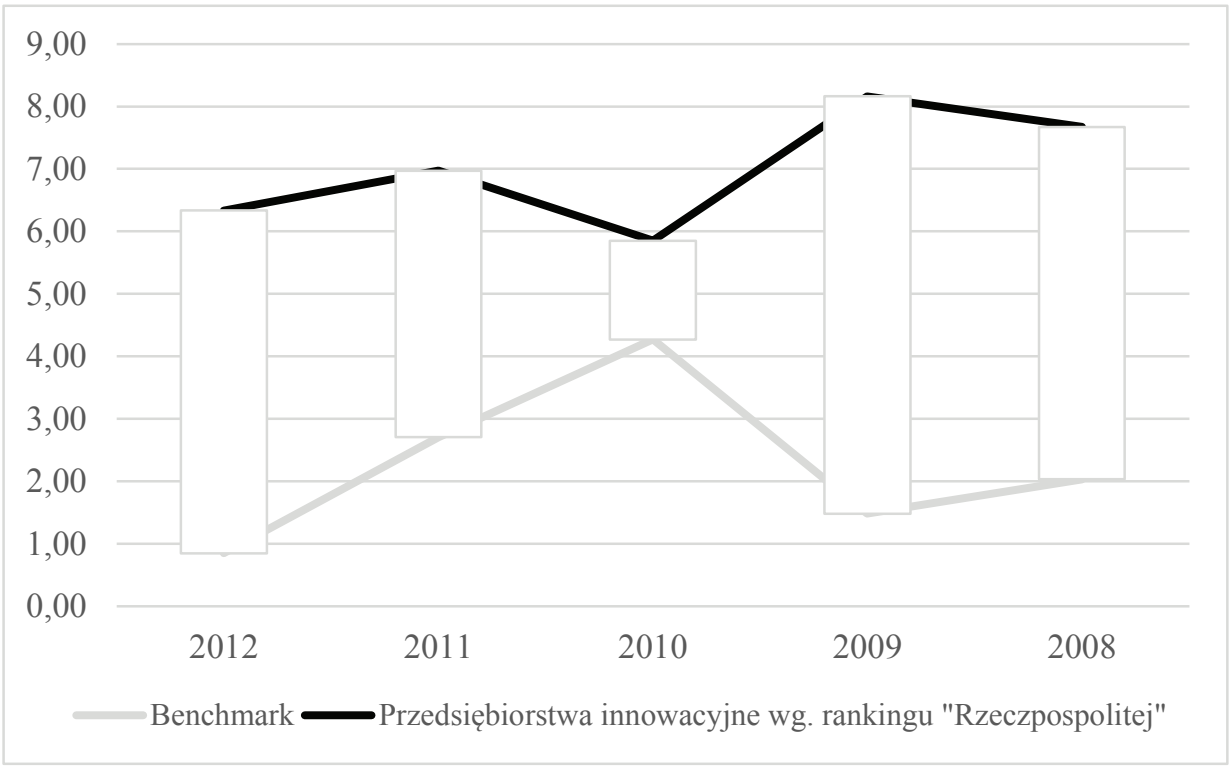

Wykres 2. Średnia obcięta wartość wskaźnika ROA (w \%) w analizowanych grupach przedsiębiorstw w latach 2008-2012

Wyniki analogiczne do tych uzyskanych z wykorzystaniem wskaźników ROE i ROA zaobserwować można przy analizie średniej marży zysku (tabela 4, wykres 3). W grupie firm innowacyjnych była ona o od 2,16 do 6,8 p.p. wyższa niż $w$ pozostałych przedsiębiorstwach. Biorąc pod uwagę dolny przedział ufności dla średniej wartości marży w firmach innowacyjnych był on dodatni we 
wszystkich analizowanych okresach, w przypadku benchmarku - jedynie w latach 2010 i 2011. Górny przedział ufności firm innowacyjnych w latach 2008, 2009 i 2012 był kilkakrotnie wyższy niż w pozostałych podmiotach.

Tabela 4. Średnia obcięta i przedziały ufności dla średniej wartości wskaźnika marży zysku (w \%) w analizowanych grupach przedsiębiorstw w latach 2008-2012

\begin{tabular}{|c|c|c|c|c|c|c|c|}
\hline \multicolumn{3}{|c|}{ Wyszczególnienie } & 2012 & 2011 & 2010 & 2009 & 2008 \\
\hline \multirow{3}{*}{ Benchmark } & \multicolumn{2}{|c|}{ 5-procentowa średnia obcięta } & 1,9446 & 5,2231 & 5,4867 & 1,8855 & 2,6539 \\
\hline & \multirow{2}{*}{$\begin{array}{l}\text { 95-procentowy } \\
\text { przedział ufności } \\
\text { dla średniej }\end{array}$} & $\begin{array}{l}\text { dolna } \\
\text { granica }\end{array}$ & $-1,0899$ & 2,8020 & 3,7967 & $-1,2027$ & $-1,3681$ \\
\hline & & \begin{tabular}{|l} 
górna \\
granica
\end{tabular} & 2,6105 & 6,2198 & 6,7970 & 2,6309 & 2,8528 \\
\hline \multirow{3}{*}{$\begin{array}{l}\text { Przedsiębiorstwa } \\
\text { innowacyjne } \\
\text { według rankingu } \\
\text { „Rzeczpospolitej” }\end{array}$} & \multicolumn{2}{|c|}{ 5-procentowa średnia obcięta } & 7,2303 & 8,8674 & 7,6433 & 8,7197 & 7,4332 \\
\hline & \multirow{2}{*}{$\begin{array}{l}\text { 95-procentowy } \\
\text { przedział ufności } \\
\text { dla średniej }\end{array}$} & $\begin{array}{l}\text { dolna } \\
\text { granica }\end{array}$ & 3,8091 & 5,8452 & 4,5801 & 0,9700 & 2,6803 \\
\hline & & $\begin{array}{l}\text { górna } \\
\text { granica }\end{array}$ & 10,6943 & 11,9798 & 11,2996 & 13,3099 & 13,1026 \\
\hline
\end{tabular}

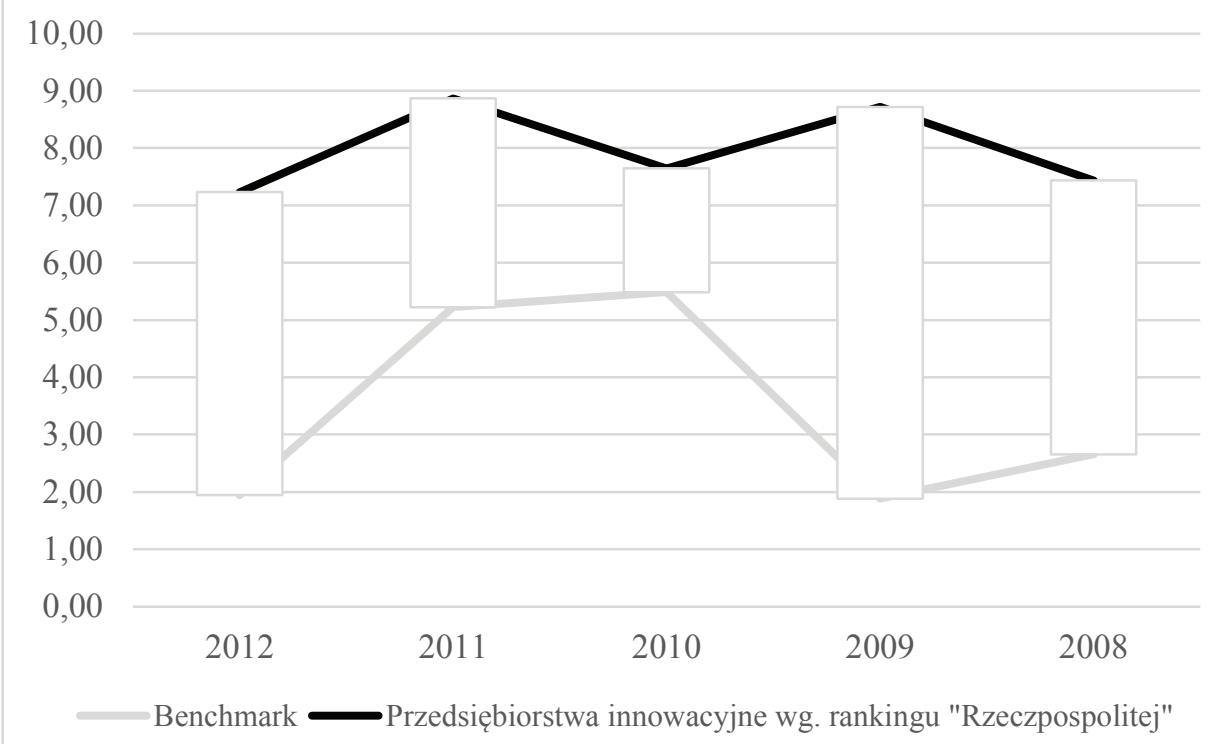

Wykres 3. Średnia obcięta wartość wskaźnika marży zysku (w \%) w analizowanych grupach przedsiębiorstw w latach 2008-2012 
Przeprowadzona w ramach niniejszego badania uproszczona analiza efektywności gospodarowania na podstawie wskaźników ROE, ROA i marży zysku wskazuje, że grupa przedsiębiorstw innowacyjnych uzyskała istotnie wyższe wyniki niż grupa przedsiębiorstw kontrolnych we wszystkich analizowanych latach. Najmniejszą różnicę w wynikach zaobserwować można w roku 2010 - mogło być to spowodowane ograniczeniem inwestycji i prac rozwojowych w przedsiębiorstwach, co jest skutkiem kryzysu gospodarczego. Niemniej jednak $\mathrm{w}$ kolejnych latach różnica $\mathrm{w}$ uzyskiwanych wynikach ponownie zwiększyła się - na korzyść przedsiębiorstw innowacyjnych. Choć horyzont czasowy próby badawczej nie jest długi, uwagę zwracają także niższe wahania wyników spółek innowacyjnych w stosunku do grupy porównawczej. Przedsięwzięcia innowacyjne często wymagają dużych nakładów kapitałowych, a zwrot $\mathrm{z}$ takiej inwestycji trwa długo. Nie potwierdzają tego przytoczone wyniki - prawdopodobnie ze względu na specyfikę działań innowacyjnych polskich firm, które w głównej mierze skupiają swoją uwagę na przedsięwzięciach stosunkowo małych i najczęściej nie mających charakteru globalnego. Autor zdaje sobie także sprawę, że wykorzystanie jedynie trzech mierników efektywności gospodarowania nie wyczerpuje w całości tej tematyki. Jednakże, biorąc pod uwagę jednoznaczność uzyskanych wyników, można przyjąć, że firmy innowacyjne cechują się wyższą efektywnością niż przedsiębiorstwa działające w sposób tradycyjny. Skoro więc wyniki tych spółek są przeciętnie wyższe od innych podmiotów, powinno to mieć swoje odzwierciedlenie w preferencjach inwestorów giełdowych. Analizie tej zależności poświęcono kolejną część opracowania.

\section{Wyniki badań wskaźników rynkowych przedsiębiorstw innowacyjnych}

W czasach praktycznie nieograniczonego dostępu do informacji na podejmowanie decyzji inwestycyjnych wpływ ma wiele danych rynkowych. Do najpowszechniej stosowanych wskaźników rynkowych pomagających w ocenie potencjału wzrostowego spółek giełdowych należą wskaźniki P/E (Price-Earnings Ratio) i P/BV (Price to Book Value Ratio). Analiza poziomu tych wskaźników pozwoli na weryfikację, czy wyższa efektywność gospodarowania spółek innowacyjnych będzie miała przełożenie na ich notowania na rynku kapitałowym.

Wskaźnik P/E wywodzi się z grupy wskaźników rynkowych, które wykorzystywane są przez inwestorów do oceny atrakcyjności inwestycyjnej spółek. Jego wartość określa czas, w jakim nastąpi zwrot nakładów zainwestowanych w dane przedsiębiorstwo przy założeniu stałej wartości zysków przedsiębiorstwa $^{10}$. Ze względu na fakt, że cena akcji z końca danego roku nie zawsze

${ }^{10}$ M. Sierpińska, T. Jachna, Ocena przedsiębiorstwa wedlug standardów światowych, Wyd. Nauk. PWN, Warszawa 2011, s. 114. 
odzwierciedla to, co działo w jego trakcie, autor zdecydował się uzupełnić analizę o wartości wskaźnika $\mathrm{P} / \mathrm{E}$ na podstawie wartości średnich w każdym roku. Przeciętne wartości wskaźnika z wyłączeniem 5\% obserwacji skrajnych oraz przedziały ufności dla średniej analizowanych grup przedsiębiorstw przedstawiono w tabelach 5 i 6 oraz na wykresie 4 .

Tabela 5. Średnia obcięta i przedziały ufności dla średniej wartości wskaźnika P/E (na koniec każdego) roku w analizowanych grupach przedsiębiorstw w latach 2008-2012

\begin{tabular}{|c|c|c|c|c|c|c|c|}
\hline \multicolumn{3}{|c|}{ Wyszczególnienie } & 2012 & 2011 & 2010 & 2009 & 2008 \\
\hline \multirow{3}{*}{ Benchmark } & \multicolumn{2}{|c|}{ 5-procentowa średnia obcięta } & 19,8048 & 17,4421 & 26,9326 & 23,3927 & 11,8487 \\
\hline & \multirow{2}{*}{$\begin{array}{l}\text { 95-procentowy } \\
\text { przedział ufności } \\
\text { dla średniej }\end{array}$} & $\begin{array}{l}\text { dolna } \\
\text { granica }\end{array}$ & 27,4142 & 22,5777 & 33,5603 & 24,7102 & 11,4172 \\
\hline & & $\begin{array}{l}\text { górna } \\
\text { granica }\end{array}$ & 45,6338 & 35,5686 & 56,6904 & 45,9565 & 20,0861 \\
\hline \multirow{3}{*}{$\begin{array}{l}\text { Przedsiębiorstwa } \\
\text { innowacyjne } \\
\text { według rankingu } \\
\text { „Rzeczpospolitej” }\end{array}$} & \multicolumn{2}{|c|}{ 5-procentowa średnia obcięta } & 14,9169 & 14,9933 & 33,1517 & 14,6521 & 18,8160 \\
\hline & \multirow{2}{*}{$\begin{array}{l}\text { 95-procentowy } \\
\text { przedział ufności } \\
\text { dla średniej }\end{array}$} & $\begin{array}{l}\text { dolna } \\
\text { granica }\end{array}$ & 11,5305 & 8,5700 & 12,3876 & 10,7643 & 8,4075 \\
\hline & & $\begin{array}{l}\text { górna } \\
\text { granica }\end{array}$ & 19,7142 & 28,0808 & 68,1986 & 18,9232 & 33,0958 \\
\hline
\end{tabular}

Tabela 6. Średnia obcięta i przedziały ufności dla średniej wartości wskaźnika P/E (przeciętnie w danym roku) w analizowanych grupach przedsiębiorstw w latach 2008-2012

\begin{tabular}{|c|c|c|c|c|c|c|c|}
\hline \multicolumn{3}{|c|}{ Wyszczególnienie } & 2012 & 2011 & 2010 & 2009 & 2008 \\
\hline \multirow{3}{*}{ Benchmark } & \multicolumn{2}{|c|}{ 5-procentowa średnia obcięta } & 23,1362 & 27,4646 & 28,7217 & 21,2137 & 22,2807 \\
\hline & \multirow{2}{*}{$\begin{array}{l}\text { 95-procentowy } \\
\text { przedział ufności } \\
\text { dla średniej }\end{array}$} & $\begin{array}{l}\text { dolna } \\
\text { granica }\end{array}$ & 30,2480 & 37,2053 & 37,4122 & 22,8099 & 21,4778 \\
\hline & & $\begin{array}{l}\text { górna } \\
\text { granica }\end{array}$ & 48,8217 & 58,5130 & 66,6976 & 45,4813 & 36,7130 \\
\hline \multirow{3}{*}{$\begin{array}{l}\text { Przedsiębiorstwa } \\
\text { innowacyjne } \\
\text { według rankingu } \\
\text { „Rzeczpospolitej” }\end{array}$} & \multicolumn{2}{|c|}{ 5-procentowa średnia obcięta } & 16,8053 & 16,8618 & 33,7679 & 13,2267 & 24,6292 \\
\hline & \multirow{2}{*}{$\begin{array}{l}\text { 95-procentowy } \\
\text { przedział ufności } \\
\text { dla średniej }\end{array}$} & $\begin{array}{l}\text { dolna } \\
\text { granica }\end{array}$ & 10,1085 & 8,8555 & 12,3425 & 9,6778 & 12,9301 \\
\hline & & $\begin{array}{l}\text { górna } \\
\text { granica }\end{array}$ & 26,4726 & 33,8130 & 69,3522 & 16,5252 & 39,2159 \\
\hline
\end{tabular}




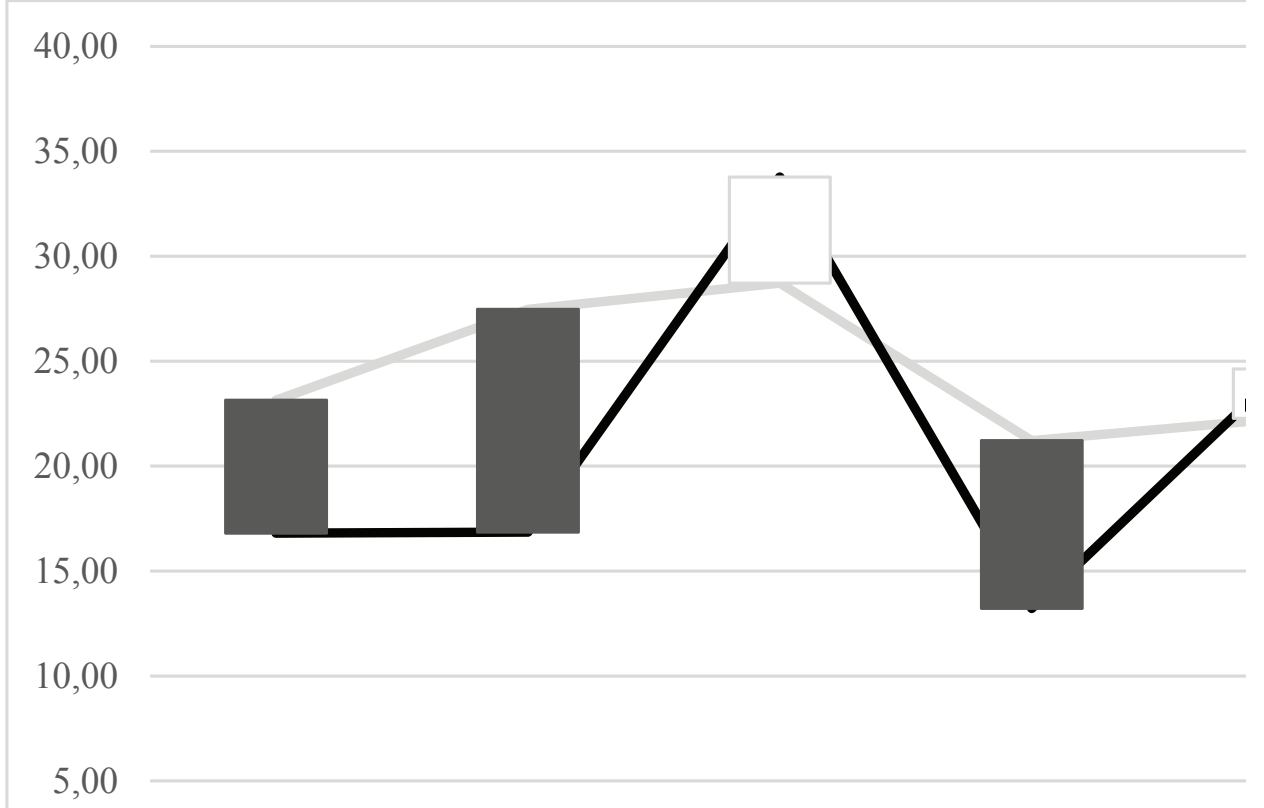

Wykres 4. Średnia obcięta wartość wskaźnika P/E (przeciętnie w danym roku) w analizowanych grupach przedsiębiorstw w latach 2008-2012

W latach 2009, 2011 i 2012 5-procentowa średnia obcięta wartość wskaźnika P/E dla grupy spółek kontrolnych była wyższa niż dla spółek innowacyjnych. Także dolna i górna granica przedziału ufności dla średniej wartości tego wskaźnika były usytuowane wyżej. W latach 2008 i 2010, choć średnia i górna granica były wyższa dla grupy spółek innowacyjnych, to już dolna granica przedziału ufności kształtowała się wyżej w grupie kontrolnej. Wyniki te, choć niejednoznaczne, wskazują, że inwestorzy są skłonni zapłacić więcej za 1 zł zysku w przypadku spółek nieinnowacyjnych.

Drugim wykorzystanym w analizie wskaźnikiem rynkowym jest relacja P/BV, która pokazuje, jak rynek wycenia daną spółkę w relacji do wartości księgowej zainwestowanych w nią kapitałów. Wysoka wartość wskaźników rynkowych z jednej strony świadczy o dużym zainteresowaniu inwestorów tymi walorami, a z drugiej zwiększa ryzyko inwestowania. Analogicznie do przypadku relacji P/E posłużono się wartościami na koniec roku (tabela 7) oraz średnimi w kolejnych okresach (tabela 8, wykres 5). 
Tabela 7. Średnia obcięta i przedziały ufności dla średniej wartości wskaźnika P/BV (na koniec każdego roku) w analizowanych grupach przedsiębiorstw w latach 2008-2012

\begin{tabular}{|l|l|l|c|c|c|c|c|}
\hline \multicolumn{3}{|c|}{ Wyszczególnienie } & 2012 & 2011 & 2010 & 2009 & 2008 \\
\hline \multirow{2}{*}{ Benchmark } & 5-procentowa średnia obcięta & 1,5932 & 1,5638 & 2,1283 & 1,2949 & 0,9721 \\
\cline { 2 - 8 } & $\begin{array}{l}\text { 95-procentowy } \\
\text { przedział ufności dla } \\
\text { średniej }\end{array}$ & $\begin{array}{l}\text { dolna } \\
\text { granica }\end{array}$ & 1,5648 & 1,7193 & 2,1275 & 1,1820 & 0,9296 \\
\cline { 2 - 8 } & $\begin{array}{l}\text { górna } \\
\text { granica }\end{array}$ & 4,2526 & 2,5520 & 3,4584 & 1,7033 & 1,4748 \\
\hline \multirow{2}{*}{$\begin{array}{l}\text { Przedsiębiorstwa } \\
\text { innowacyjne } \\
\text { według rankingu } \\
\text { „Rzeczpospolitej” }\end{array}$} & $\begin{array}{l}\text { 5-procentowa średnia obcięta } \\
\text { przedział ufności dla }\end{array}$ & 1,4847 & 1,5145 & 1,9783 & 1,7322 & 1,2315 \\
\cline { 2 - 8 } & średniej & $\begin{array}{l}\text { dolna } \\
\text { granica }\end{array}$ & 1,0744 & 0,9499 & 1,1857 & 0,8466 & 0,6087 \\
\cline { 2 - 8 } & $\begin{array}{l}\text { górna } \\
\text { granica }\end{array}$ & 2,0451 & 2,5207 & 3,1576 & 3,3439 & 2,1666 \\
\hline
\end{tabular}

Tabela 8. Średnia obcięta i przedziały ufności dla średniej wartości wskaźnika P/BV (przeciętnie w danym roku) w analizowanych grupach przedsiębiorstw w latach 2008-2012

\begin{tabular}{|c|c|c|c|c|c|c|c|}
\hline \multicolumn{3}{|c|}{ Wyszczególnienie } & 2012 & 2011 & 2010 & 2009 & 2008 \\
\hline \multirow{3}{*}{ Benchmark } & \multicolumn{2}{|c|}{ 5-procentowa średnia obcięta } & 2,0405 & 2,3381 & 2,2038 & 1,2162 & 1,8504 \\
\hline & \multirow{2}{*}{$\begin{array}{l}\text { 95-procentowy } \\
\text { przedział ufności dla } \\
\text { średniej }\end{array}$} & $\begin{array}{l}\text { dolna } \\
\text { granica }\end{array}$ & 1,4637 & 2,3297 & 2,2550 & 1,1383 & 1,5736 \\
\hline & & $\begin{array}{l}\text { górna } \\
\text { granica }\end{array}$ & 4,5913 & 4,1116 & 4,8702 & 1,7556 & 3,8486 \\
\hline \multirow{3}{*}{$\begin{array}{l}\text { Przedsiębiorstwa } \\
\text { innowacyjne } \\
\text { według rankingu } \\
\text { „Rzeczpospolitej” }\end{array}$} & \multicolumn{2}{|c|}{ 5-procentowa średnia obcięta } & 1,5786 & 1,7759 & 1,8603 & 1,5236 & 1,8296 \\
\hline & \multirow{2}{*}{$\begin{array}{l}\text { 95-procentowy } \\
\text { przedział ufności dla } \\
\text { średniej }\end{array}$} & $\begin{array}{l}\text { dolna } \\
\text { granica }\end{array}$ & 1,1596 & 1,1750 & 1,1894 & 0,6415 & 0,6757 \\
\hline & & $\begin{array}{l}\text { górna } \\
\text { granica }\end{array}$ & 2,0795 & 2,6825 & 2,8670 & 3,1818 & 3,7851 \\
\hline
\end{tabular}

W latach 2008 i 2010-2012 zarówno 5-procentowa średnia obcięta, jak i przedział ufności dla średniej wartości wskaźnika P/BV były wyższe w grupie przedsiębiorstw kontrolnych. Jedynie w roku 2009 przedsiębiorstwa innowacyjne osiągnęly wyższy rezultat obciętej wartości przeciętnej i górnej granicy przedziału ufności. Wynika z tego, że inwestorzy w większości przypadków nie są skłonni zapłacić więcej za 1 zł wartości kapitałów księgowych firm innowacyjnych $\mathrm{w}$ porównaniu $\mathrm{z}$ pozostałymi podmiotami. Zróżnicowana rozpiętość przedziałów ufności w poszczególnych grupach nie upoważnia też do stwierdzenia, wyniki której z grup cechowały się większą zmiennością. 


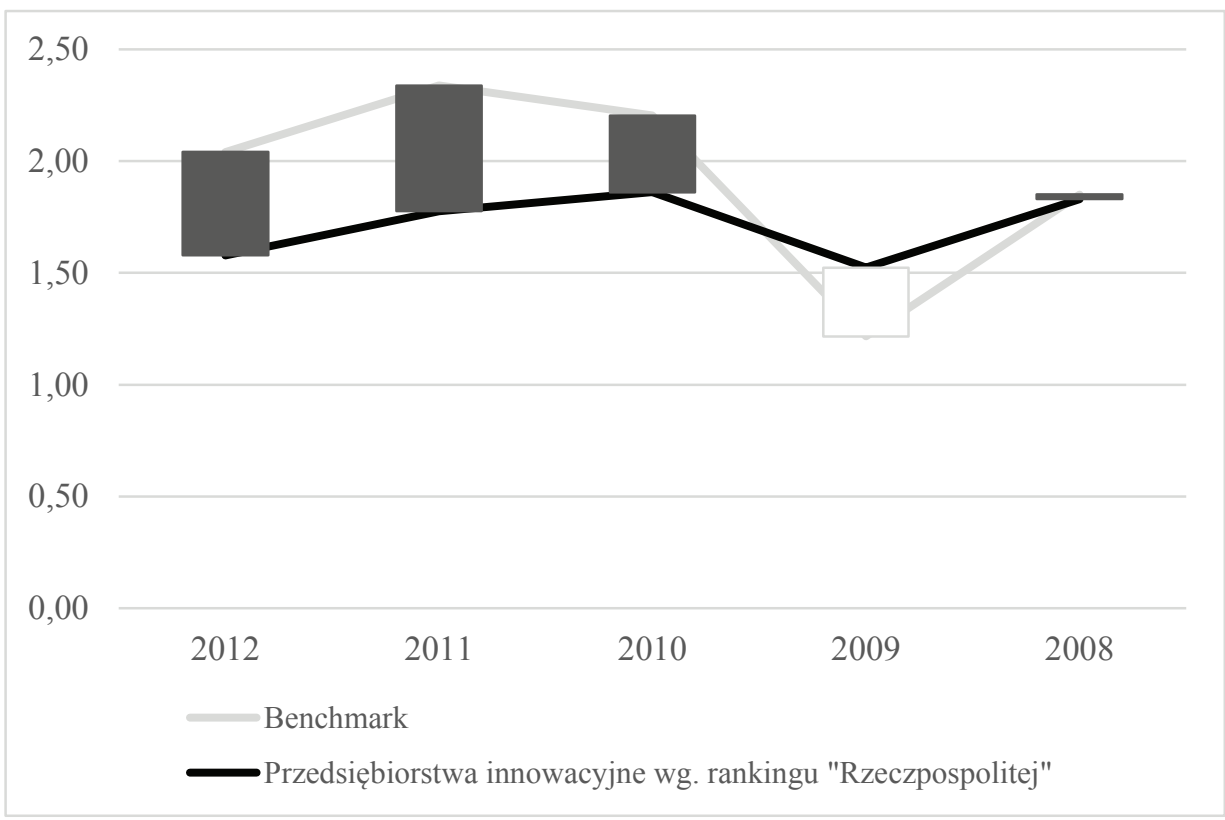

Wykres 5. Średnia obcięta wartość wskaźnika P/BV (przeciętnie w danym roku) w analizowanych grupach przedsiębiorstw w latach 2008-2012

Analiza wartości przeciętnych wskaźników rynkowych wykazała, że sam status przedsiębiorstwa innowacyjnego nie ma pozytywnego wpływu na jego postrzeganie przez inwestorów. Na tle benchmarku inwestorzy przeciętnie są skłonni zapłacić mniej zarówno za 1 zł zysku, jak i 1 zł kapitału księgowego podmiotów innowacyjnych. Zestawiając uzyskane wyniki z uproszczoną analizą efektywności gospodarowania należy dodatkowo stwierdzić, że nawet przeciętnie wyższa efektywność uzyskana przez przedsiębiorstwa z grupy innowacyjnej we wszystkich analizowanych latach nie ma bezpośredniego przełożenia na wyższe wartości wskaźników rynkowych.

\section{Zakończenie}

Wyniki większości badań przeprowadzonych na rynku Stanów Zjednoczonych i Europy Zachodniej świadczą o pozytywnym wpływie działań innowacyjnych na rynkowe stopy zwrotu i wartość rynkową przedsiębiorstw. W realiach polskiego rynku kapitałowego trudność w przeprowadzeniu badań o podobnym zakresie wynika przede wszystkim z ograniczonego dostępu do danych empirycznych związanych z działalnością innowacyjną. Przedsiębiorstwa, dążąc do ochrony swojej własności intelektualnej, starają się ograniczać udostępnianie 
tego typu informacji nawet do badań statystycznych. Przeprowadzone w niniejszym opracowaniu badanie miało na celu weryfikację dwóch kluczowych aspektów funkcjonowania przedsiębiorstw innowacyjnych. Pierwszy związany był z uzyskiwaną efektywnością gospodarowania, która dzięki zastosowaniu rozwiązań innowacyjnych powinna być wyższa. Wyniki z lat 2008-2012 świadczą, że przedsiębiorstwa innowacyjne osiągały rentowność kapitału własnego, aktywów oraz marżę zysku na poziomie istotnie wyższym niż pozostałe przedsiębiorstwa.

Drugim istotnym zagadnieniem związanym $\mathrm{z}$ działalnością innowacyjną jest pozyskanie kapitału na ich finansowanie. Jedną z możliwości jest wykorzystanie do tego celu środków z rynku kapitałowego. Analiza tego zakresu, przeprowadzona $\mathrm{z}$ wykorzystaniem rynkowych wskaźników P/E i P/BV, nie dała jednoznacznych rezultatów. Jednakże $\mathrm{w}$ większości analizowanych okresów inwestorzy nie byli skłonni zapłacić więcej na 1 zł kapitałów księgowych spółek innowacyjnych $\mathrm{w}$ porównaniu z pozostałymi przedsiębiorstwami. Wytłumaczeniem takiego stanu rzeczy może być awersja inwestorów do ponoszenia większego ryzyka związanego z zakupem akcji spółek innowacyjnych. Następnym powodem może być nieefektywna komunikacja spółek innowacyjnych z inwestorami. Badania przeprowadzone przez M. Appolloni, R. Corigliano, A. Duqi i G. Torluccio ${ }^{11}$ wykazały, że jednym z kluczowych czynników wpływających na pozytywny odbiór faktu prowadzenia działalności $\mathrm{B}+\mathrm{R}$ przez inwestorów giełdowych jest informowanie o zamiarach, postępach i wynikach prowadzonych prac.

W literaturze związanej $\mathrm{z}$ działalnością innowacyjną niejednokrotnie udowodniono, że innowacje są praktycznie jedyną drogą do długoterminowego wzmacniania pozycji konkurencyjnej przedsiębiorstw. Choć wyniki badań nie wskazują, że przedsięwzięcia innowacyjne przyczyniają się do lepszego postrzegania spółek prowadzących taką działalność przez inwestorów, $\mathrm{w}$ opinii autora nie powinno to zniechęcać spółek do inwestycji w $\mathrm{B}+\mathrm{R}$. Badania A. Duqi, R. Mirti i G. Torluccio ${ }^{12}$ dowodzą, że działania innowacyjne mają tym większy wpływ na wartości wskaźników rynkowych i wycenę rynkową spółek, im wyższe są ogólne wydatki na B+R w danym kraju. Można zatem przypuszczać, że wraz ze wzrostem poziomu innowacyjności Polski na tle Europy inwestorzy zaczną uwzględniać i wartościować w swoich wyborach inwestycyjnych fakt wprowadzania przez przedsiębiorstwa przedsięwzięć innowacyjnych.

${ }^{11}$ M. Appolloni, R. Corigliano, A. Duqi, G. Torluccio, The Market Value..., s. 166.

${ }^{12}$ A. Duqi, R. Mirti, G. Torluccio, An Anlysis of the R\&D Effect on Stock Returnsfor European Listed Firms, „European Journal of Scientific Research” 2011, vol. 58, No 4, s. 489-490. 


\section{Literatura}

Appolloni M., Corigliano R., Duqi A., Torluccio G., The Market value of innovation, „European Journal of Economics, Finance \& Administrative Sciences” 2011, vol. 8, Issue 36.

Duqi A., Mirti R., Torluccio G., An Anlysis of the R\&D Effect on stock returns for European listed firms, ,European Journal of Scientific Research” 2011, vol. 58, No 4.

Innovation Union Scoreboard 2013. Enterprise and Industry, European Union 2013.

Jabłońska Ż., Socha B., Efektywność gospodarowania a wycena rynkowa przedsiębiorstw innowacyjnych na polskim rynku kapitałowym, [w:] P. Urbanek (red.), Ekonomia i zarzadzanie $w$ teorii i praktyce. Polityka ekonomiczna i zarzadzanie przedsiębiorstwem $w$ warunkach kryzysu gospodarczego, t. 3, Wyd. UŁ, Łódź 2011.

Jesteśmy w ogonie innowacyjności, „Rzeczpospolita”, 27.06.2013.

„Lista 2000. Polskie przedsiębiorstwa”, dodatek do gazety „Rzeczpospolita”, 24.10.2012.

Parthasarathy R., Chenglei H., Aris S., Impact of dynamic capability on innovation, value creation and industry leadership, „IUP Journal of Knowledge Management” 2011, vol. 9, issue 3.

Poland Corporate R\&D Report 2013, Deloitte, June 2013.

Pomykalski P., Finansowanie innowacji przedsiębiorstwa, [w:] S. Bakalarczyk, P. Pomykalski (red.), Innowacyjność organizacji, Difin, Warszawa 2008.

Szuszyński C. (red.), Przedsiębiorstwo. Wartość. Zarządzanie, PWE, Warszawa 2007.

\section{Streszczenie}

W opracowaniu przedstawiono analizę empiryczną efektywności gospodarowania i pozycji rynkowej publicznych przedsiębiorstw innowacyjnych w latach 2008-2012. Uzyskane wyniki sugerują, że wprowadzenie przedsięwzięć innowacyjnych ma pozytywny wpływ na rentowność kapitału własnego, aktywów i marżę zysku, jednakże nie zawsze ma to swoje odbicie w pozycji rynkowej podmiotów mierzonej wskaźnikami rynkowymi $\mathrm{P} / \mathrm{E}$ i $\mathrm{P} / \mathrm{BV}$.

\section{Summary}

\section{FINANCIAL PERFORMANCE AND MARKET POSITION OF PUBLIC INNOVATIVE COMPANIES IN POLAND}

This paper presents an empirical study which is conducted to test the effectiveness and the market position of public innovative enter rises in 2008-2012. The results may suggest that the innovative projects have positive impact on return on equity, assets and profit margin. Better effectiveness is not always reflected in the market position. 